\title{
ARTIGO
}

Sociologias, Porto Alegre, ano 6, no 11, jan/jun 2004, p. 260-299

\section{Modernidade, disciplina e futebol: uma análise sociológica da produção social do jogador de futebol no Brasil ${ }^{1}$}

FRANCISO XAVIER FREIRE RODRIGUES*

Introdução

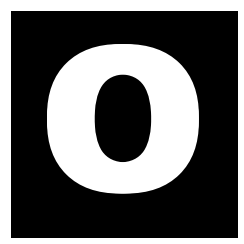

presente trabalho tem por objetivo investigar a relação entre modernidade, disciplina e formação do jogador de futebol profissional. Discute o futebol moderno como instituição disciplinadora e civilizadora, dotada de regras, normas e princípios científicos (positividades), tendo como objetivo produzir, manipular, individualizar, adestrar e aperfeiçoar o corpo do indivíduo, tornar o jogador dócil e utilitário. Traça um breve paralelo entre a produção social do soldado e a do jogador de futebol, entendendo tal processo como resultado do poder disciplinar nas respectivas instituições das quais são produtos. O referencial teórico adotado é a teoria do poder disciplinar de Michel Foucault $(2001,1987)$ e a teoria do processo civilizador de Norbert Elias (1992).

Trata-se de uma pesquisa empírica sobre a formação profissional do jogador de futebol no Brasil, tendo como recorte empírico as categorias de base (juvenil e júnior) e profissional do Sport Club Internacional de Porto Alegre, RS. ${ }^{2}$

* Mestre e doutorando em Sociologia no PPGS/UFRGS.

1 Este texto sintetiza uma série de discussões realizadas na dissertação de Mestrado em Sociologia (UFRGS) defendida em 13/01/2003. O autor agradece aos comentários e orientações do Prof. Dr. Enno D. Liedke Filho.

2 O SC Internacional, fundado em 1909, tem sua sede em Porto Alegre (RS), é um time da Primeira Divisão dos Campeonatos Brasileiro e Gaúcho. É tri-campeão brasileiro (1975, 1976 e 1979) e campeão de uma Copa do Brasil (1992). 
O procedimento metodológico consistiu inicialmente numa revisão da literatura sociológica especializada. Utilizaram-se entrevistas semiestruturadas, com seis atletas, sendo três da categoria juvenil e três da categoria profissional. Aplicaram-se 56 questionários, divididos da seguinte forma: 20 na categoria juvenil, 20 entre os atletas juniores e 16 na categoria profissional. Realizaram-se entrevistas com dirigentes e técnicos.

O texto está dividido da seguinte forma: 1) A modernidade: poder disciplinar e a produção social do jogador de futebol. 2) Breve história do futebol brasileiro; 3) Modernização no futebol brasileiro: a intervenção científica na formação do jogador de futebol nos anos 90; 4) Modernização e futebol científico no SC Internacional: a década de 90; 5) Motivação profissional, sacrifícios e disciplinamento do jogador de futebol no SC Internacional; 6) Considerações finais.

\section{A modernidade: poder disciplinar e a produção social do jogador de futebol}

A modernidade caracteriza-se pela descontinuidade, fragmentação, ruptura e deslocamento do sujeito de estruturas tradicionais (Giddens, 1991; Harvey, 1992; e Laclau, 1990). A era moderna inicia com a superação da ordem medieval, provocando alterações em praticamente todas as dimensões da vida humana. A modernidade enquanto projeto de civilização assenta-se num conjunto de valores como racionalidade, individualismo, autonomia, desencantamento do mundo e universalidade. Valores estes apresentados como universais. A explicação das relações sociais travadas na modernidade é o propósito maior da Sociologia como ciência.

Os clássicos da Sociologia trataram a modernidade, em determinados aspectos, de modo semelhante, entendendo-a como época nova, oposta ao passado, caracterizada por rupturas nas diversas esferas da vida social. Trata-se de um momento de expansão social do saber e dos domínios sobre 
Sociologias, Porto Alegre, ano 6, no 11, jan/jun 2004, p. 260-299

a natureza, entre os homens e as possibilidades de progresso. Nesta perspectiva, a modernidade é antinatural, antitradicional, antimetafísica, tendo como polaridades básicas: social/natural, moderno/tradicional, racional/emocional, científico/metafísico. Existe associação entre universalismo e individualismo como tendência moderna: este é o entendimento comum entre os clássicos.

Na sociologia clássica, o mundo moderno é marcado pela sociedade dos indivíduos. Os homens têm interesses, ações liberadas, quebrando barreiras, mas criando outras, como o Estado de Direito (Durkheim), Burocracia (Weber) e circuito do capital (Marx). A civilização moderna pode ser entendida como uma cultura racionalista, que tem como pilares o individualismo (o homem moderno), universalismo (o contexto moderno como inovação histórica) e cognitivismo (a ciência moderna). É necessário ressaltar que as concepções sobre a modernidade e a racionalidade são diferentes. Em Marx percebe-se uma crítica ao caráter e ao uso burguês da ciência e sua conseqüente transformação em força produtiva. Weber preocupou-se em sublinhar a singularidade da cultura ocidental, sendo a racionalização o componente-chave dessa cultura. Em Durkheim verificamos a ênfase da dimensão coletivista da racionalidade.

A individualidade do homem é uma condição para a universalidade. Implica ruptura com a tradição, ensejando novas bases de intercâmbio dos indivíduos. É, portanto, o momento no qual culmina o processo de separação entre o homem e natureza. Marca o advento de determinado tipo de interesse pelo corpo.

1.1 Poder disciplinar, processo civilizador e formação do indivíduo moderno: aplicando Foucault e Elias à análise do futebol

Em Vigiar e Punir, Foucault (1987) elabora uma genealogia do direito penal racionalizado e da execução penal cientificamente humanizada. Sua análise centra-se no surgimento do regime moderno de poder, que busca o 
afinamento e a adaptação aos instrumentos que vigiam a identidade, os gestos, as atividades e os comportamentos cotidianos dos indivíduos. O poder é imposto por meio de processos de aprendizagem prático-moral, contribuindo com o adestramento dos indivíduos através da socialização.

As instituições sociais modernas escola, fábrica, hospital, polícia disciplinam o indivíduo, manipulam e controlam o corpo. A ordem social moderna se sustenta na sua capacidade de comando e direção, permitida pelo conjunto de instituições e organizações administrativas. A manipulação ocorre através do disciplinamento por meio das instituições sociais. O esporte moderno pode ser considerado como instituição disciplinadora dos corpos. Esta concepção integra a obra de Muller, Dieguez e Gabauer (Bracht, 1997, p. 46), o que nos possibilita investigar o futebol como instituição disciplinadora de corpos.

A análise de Foucault acerca do poder preocupa-se em captá-lo em suas extremidades (capilar, ramificações), manifesto nas instituições locais e regionais, examinado sua materialização. O poder como algo que circula, que funciona em cadeia e redes (Foucault, 2001, p. 182-3). O poder passa sobre os indivíduos, fazendo com que os gestos, corpos, desejos e discursos funcionem e sejam identificados como indivíduos. O indivíduo é um efeito do poder, sendo criação e veículo de transmissão. A idéia de poder como rede, micro, estendendo-se ao conjunto de esferas sociais pode ser aplicada à análise do futebol, especialmente das relações de controle social, condicionamentos físicos, técnicos e táticos, ordenamentos e hierarquia das posições. O técnico revela seu poder por meio dos esquemas, os atletas procuram sempre "escutar e fazer o que o técnico manda" (Rincón, 20 anos, atleta). Trata-se de um poder disciplinar em forma de técnicas, dispositivos, métodos de controle do corpo e dos atos dos indivíduos, almejando docilidade e utilidade. Os treinamentos físicos, táticos e técnicos manipulam o corpo, na tentativa de alcançar o padrão ideal de jogador, resistente e habilidoso. Trata-se de colocar os jogadores em forma, preparados para jogar. 
A disciplina produz maneiras de agir e comportamentos, fabrica o homem necessário a determinadas funções. O poder disciplinar trabalha o corpo no sentido de torná-lo força de trabalho, capaz de proporcionar os melhores rendimentos possíveis. O jogador de futebol é uma força de trabalho produto do disciplinamento, treinamentos e do desenvolvimento de seu potencial genético (Carravetta, 2001, p. 19).

A disciplina fabrica assim corpos submissos e exercitados, corpos dóceis. A disciplina aumenta as forças do corpo (em termos econômicos de utilidade) e diminui essas mesmas forças (em termos políticos de obediência). [...], ela dissocia o poder do corpo; faz dele por um lado uma aptidão, uma capacidade que ela procura aumentar; e inverter por outro lado a energia, a potência que poderia resultar disso, e faz dela uma relação de sujeição estrita (Foucault,1987, p. 127).

A disciplina pode ser entendida como obediência técnica e tática, uma disciplina corporal e moral. O poder disciplinar manifesta-se das seguintes formas: (1) A disciplina é um tipo de organização do espaço. Distribui os corpos em espaços específicos e individuais, classifica-os, conforme determinadas funções. A disciplina constitui um controle do tempo (Machado, 2001, p. XVII). Horários marcados para as tarefas. O corpo é sujeito ao tempo, busca-se produzir com rapidez e eficácia. O que mais interessa é o desenvolvimento e não o resultado da ação. Nos clubes de futebol, existem horários marcados para treinamentos, jogos e atividades recreativas. Tem-se o controle minucioso do corpo do jogador e de suas operações, buscando articulação entre corpo e objeto manipulados. (2) A vigilância como instrumento de controle social usado pelo poder disciplinar. Trata-se do controle discreto, invisível. Por exemplo, o poder vigilante do Panopticon de Bentham (Machado, 2001, p. XVIII). Este controle, sem ser visto, existe nos clubes de futebol. Os atletas em formação reclamam da ausência de vida normal, do excesso de trabalho, dos treinos de diferentes naturezas e 
das proibições de sair à noite. Tudo isso significa controle social. É neste sentido que a noção de vigilância de Foucault é útil na investigação do controle técnico e social dentro dos clubes de futebol.

O objetivo político e econômico do poder disciplinar é tornar o corpo humano útil e dócil (Foucault, 2001). O poder disciplinar não é negativo, é positivo; ele produz o indivíduo moderno, sendo uma técnica de controle social muito eficiente desenvolvida nas sociedades modernas desde o século XIX. Para Foucault (2001, p. 183-4), “(...) o indivíduo não é o outro do poder: é um de seus primeiros efeitos. O indivíduo é um efeito do poder e simultaneamente, ou pelo próprio fato de ser um efeito, é seu centro de transmissão. $O$ poder passa através do indivíduo que ele constituiu". O poder moderno, ao invés de massificar, descaracterizar, individualiza e unifica. Numa massa desordenada, o poder faz o indivíduo emergir como alvo, esquadrinhado. $\mathrm{O}$ nascimento da prisão não é uma massificação, mas o isolamento celular, total ou parcial, uma inovação no sistema penitenciário. O nascimento do hospício não destruiu o específico da loucura, ele é produzido como doente mental, individualizado, com relações disciplinares de poder para cuidar do doente.

O mundo moderno criou conhecimentos, normas, técnicas e discursos que são operadores e legitimadores do controle do corpo. Muitos desses conhecimentos encontram-se relacionados ao mundo do esporte. Este se configura como uma das esferas das sociedades contemporâneas mais importantes de organização da corporeidade.

O esporte é um dos mais fortes vetores que potencializa o domínio do corpo. As identidades sociais modernas se constroem em torno do corpo. Vivemos em uma sociedade esportivizada, no sentido de busca pelo aperfeiçoamento do corpo para diversas finalidades estéticas e competitivas. As academias são exemplos ilustrativos de busca de corpos saudáveis, fortes e belos.

O treinamento esportivo é um aspecto relevante do esporte moderno de competição. As metodologias e os princípios de treinamento são sustentados por conhecimentos científicos, positividades e dispositivos 
contendo elementos que buscam melhorar o desempenho esportivo, sendo que uma das exigências/critérios é exatamente colocar o corpo sob um perfeito controle. É necessário operacionalizar o corpo, tornar possível alcançar elevada performance desportiva. No treinamento esportivo, o corpo aparece como um objeto passível de manipulação, adestramento e operacionalidade, comparável a uma máquina. O corpo pode ser colocado em funcionamento; para isso, recebe treinamentos especiais. Trata-se de uma consciência mecânica do corpo no esporte. A teoria do treinamento desportivo pode assemelhar-se a outras técnicas e outros discursos sobre o corpo, tais como os cuidados com dieta e estética.

\subsection{Paralelo entre a produção do soldado e a formação} do jogador de futebol moderno

A produção social do corpo pode ser analisada à luz da sociologia de Michel Foucault $(2001,1987)$. Por volta da metade do século XVIII surgem novos interesses e conhecimentos sobre o corpo. O soldado passa a ser fabricado, treinado, tornando-se praticamente uma máquina especializada, sobre a qual se exerce controle. A partir deste momento, o soldado deixa de ser um camponês recrutado para se tornar um corpo disciplinado, construído socialmente através de mecanismos disciplinares (positividades) (Foucault, 1987, p. 125).

(...) o soldado tornou-se algo que se fabrica; de uma massa informe, de um corpo inapto, fez-se a máquina de que se precisa; corrigiram-se aos poucos as posturas; lentamente uma coação calculada percorre cada parte do corpo, se assenhoreia dele, dobra o conjunto, torna-o perpetuamente disponível e se prolonga, em silêncio, no automatismo dos hábitos; em resumo, foi 'expulso o camponês' e Ihe foi dada a 'fisionomia de soldado. 
Isso nos permite fazer uma analogia com o jogador de futebol no Brasil. A figura do jogador-operário desaparece com o processo de profissionalização, momento em que se exigem mecanismos específicos e um processo de produção do jogador, um corpo útil ao futebol, um profissional. Um exemplo clássico de jogador-operário é Garrincha. Começou sua carreira futebolística no Sport Club Pau Grande em 1949, time organizado pelos operários da tecelagem Cia. América Fabril de Pau Grande, no Rio de Janeiro (Antunes, 1994, p. 109; Castro, 1995). Além de receber o salário como operário, recebia presentes e gratificações como segundo salário. É ilustrativo também o caso de Tesourinha, um dos grandes jogadores do SC Internacional na década de 40 . Ao assinar seu primeiro contrato profissional por $200 \$ 000$ mensais e mais dois litros de leite e um quilo de carne diariamente, Tesourinha continuou no seu antigo emprego de artífice de armeiro na Brigada Militar (Ostermann, 1999, p. 46).

Nos processos de produção do corpo do soldado e do jogador de futebol modernos, pode-se salientar que, em ambos os casos, trata-se de um processo de profissionalização; pode ainda ser entendida, à luz do conceito de campo (Bourdieu, 1999 e 1990), ${ }^{3}$ uma autonomização dos respectivos campos: segurança/policial e esportivo/futebolístico.

Na sociedade contemporânea, produz-se um corpo conforme a necessidade, buscando atingir o máximo de rendimento, tornar o corpo útil. Isso serve para pensar o processo de formação do jogador de futebol. Com o advento do futebol profissional, o jogador deixa de ser o operário-jogador. Exige-se que o jogador seja fabricado em escolinhas, nos clubes, disciplinado, alvo de controle, disciplina e poder.

No futebol, a vigilância classifica o atleta, seu ritmo de jogo, rendimento e sua capacidade de suportar os esforços nos treinamentos. É essa vigilância, essa disciplina que produz o jogador de futebol moderno nos clubes. Isso nos permite entender o futebol como instituição disciplinadora.

3 Campo pode ser entendido como um espaço de diferenciação social, organizado segundo regras e normas próprias, dotado de autonomia relativa frente à política, à economia e à religião, no qual os atores sociais são estratégicos, buscam maximizar seus interesses e influenciar nas definições e divisões sociais. 
A teoria do processo civilizador de Norbert Elias (1992) ${ }^{4}$ é importante na análise da formação profissional do jogador de futebol no SC Internacional, pois nos permite tencionar um pouco com a noção de poder disciplinar de Foucault. Como sabemos, Elias se preocupou com a evolução dos esportes, vendo nesta uma dimensão do processo civilizador. A introdução de normas amenizou a violência nos esportes, controlando impulsos, sublimando desejos e criando condutas em conformidade com as regras. Tal mudança resulta do processo de institucionalização e racionalização das práticas esportivas, que é inerente ao processo civilizatório (Elias, 1992).

Entender o futebol como agente civilizador será um dos desafios deste trabalho. Procuraremos perceber como os jovens atletas incorporam o conjunto de normas, regras e formas de relações sociais estabelecidas no clube. É neste sentido que a dimensão educativa do futebol será analisada.

\section{Breve história do futebol brasileiro}

A história do futebol no Brasil pode ser divida em diferentes períodos. Levine (1982, p. 23) utiliza a seguinte periodização: (a) primeira fase (18941904), (b) fase amadora (1905-1933), (c) fase do profissionalismo (19331950), (d) fase do reconhecimento internacional e da comercialização do futebol (1950-1970). Tomaremos como base essa periodização histórica, porém buscaremos avançar em termos de fatos e acontecimentos marcantes de cada época. Nosso objetivo não é reproduzir narrativas históricas sobre o futebol brasileiro, mas apresentar sumariamente o contexto no qual se desenvolve o futebol no Brasil, permitindo ao leitor compreender a relação futebol e sociedade em cada momento definido.

4 O leitor pode encontrar uma análise sistemática e profunda da teoria do processo civilizador na formação do jogador de futebol moderno no trabalho de Rodrigues (2003) A formação do jogador de futebol no Sport Club Internacional (1997-2002). Porto Alegre: PPGS/UFRGS (Dissertação de Mestrado). 
2.1 O primeiros chutes: os clubes urbanos e ingleses

A primeira fase é marcada pela chegada do futebol ao país e a criação de clubes urbanos por imigrantes europeus. Trata-se do pontapé inicial. O futebol surge no Brasil no final do século XIX, quando Charles Miller retorna da Inglaterra, em 1894, trazendo consigo materiais próprios desse esporte: bolas, camisas, calções e chuteiras. É Charles Miller quem introduz o futebol no Brasil, inicialmente no estado de São Paulo, entre os jovens da elite paulistana. O elitismo é uma marca do nascimento do futebol no Brasil. Negros e mulatos eram excluídos dessa "nobre prática esportiva", sendo esta um privilégio dos membros da elite. O futebol aparece como elemento da modernidade, "uma novidade moderna e elegante" (Pereira, 2000, p. 16), sendo "um produto de importação" (Lopes, 1994a, p. 29).

Como afirma Helal (1990, p. 38), "de início, logo após a atividade de missionário exercida por Charles Miller, o futebol teve como focos de irradiação o meio industrial e aristocrático, ligados aos hábitos de lazer da colônia européia". Cabe frisar a importância do São Paulo Athletic Club, fundado no ano de 1888, a quem Charles Miller se filiou, organizando a prática futebolística em São Paulo. Nesta fase, o futebol era praticado nos colégios de elite paulistas e cariocas Alfredo Gomes, Anglo-brasileiro (Caldas, 1990, p. 23), e em outros estados.

No Rio de Janeiro, o advento do futebol se deve ao descendente de ingleses Oscar Cox, que retornou da Suíça em 1897, onde teve contato com este esporte. Mais do que a introdução do futebol nesse estado, Cox cumpriu o papel de difusor dos jogos de bola, organizando jogos e despertando o interesse na juventude pelo futebol. Alguns relatos históricos sugerem que, antes da chegada de Cox, o futebol já era praticado por ingleses nas fábricas e nos colégios da cidade (Pereira, 2000, p. 21). No entanto, a prática futebolística não contava ainda com um sistema de regras definido, sendo um jogo praticamente selvagem. ${ }^{5}$ Cox se filiou ao Payssandu Cricket Club, uma agremiação futebolística fundada por ingleses em 1892.

5 Pode-se dizer que o futebol não era ainda um campo autônomo, dotado de regras especiais definidas por seus atores. 
A Igreja Católica e os colégios incentivaram a prática futebolística nesse período.

(...) no Brasil foram justamente os colégios que muito cedo se tornaram as forjas de futebolistas: em escolas como os colégios militares, o Ginásio Nacional, o Alfredo Comes, o Abílio, o Anglo-Brasileiro, o futebol era quase uma matéria obrigatória. A Igreja Católica, fator de enorme importância, parece não ter levantado nenhuma objeção. Deve-se até salientar o fato de que numerosos padres deram impulso decisivo para a difusão do novo jogo. Uma certa notoriedade conseguiu o padre Manuel Gonzáles, que deve ter fabricado a primeira bola brasileira de couro cru, para que seus alunos do Colégio Vicente de Paula (Petrópolis) pudessem dedicar-se ao esporte (Rosenfeld, 1993, p. 78).

Nesta fase, é importante destacar a fundação do "The Bangu Athletic Club", em 1904, por ingleses funcionários da Companhia Progresso Industrial Ltda., uma fábrica de tecidos localizada no bairro Bangu. Esse clube, o mais famoso clube de fábrica, logo teve que aceitar jogadores-operários para completar o número de jogadores exigido, pois os funcionários eram insuficientes para formar duas equipes necessárias à disputa de um match, como era chamado na época.

O critério de escolha do jogador baseava-se principalmente em três aspectos: no seu desempenho profissional, no tempo de serviço na empresa e no comportamento pessoal. Ao ser escolhido, o jogador-operário passaria imediatamente a desempenhar um tipo de trabaIho mais leve, onde pudesse economizar suas energias para concentrá-las no futebol. Nos dias de treino, ele tinha autorização dos diretores da empresa para deixar o trabalho mais cedo, com uma condição: dirigir-se ao campo de futebol, a fim de realizar os treinos coletivos 
(Caldas, 1990, p. 29).

Na verdade, estava dado um dos primeiros e mais importantes passos na democratização do futebol brasileiro, bem como na difusão do esporte entre os operários que, mais tarde, seriam exatamente os operários da bola, profissionais do futebol.

\subsection{Amadorismo e elitismo: o futebol como distinção social}

O período elitista do futebol brasileiro corresponde ao amadorismo. O futebol era símbolo de distinção social, um bem restrito à elite econômica e cultural. A fase amadora, geralmente datada de 1905 a 1933, caracteriza-se pelo elitismo na platéia e na composição dos times (Lopes, 1994a, p. 70) e pela ampla divulgação na imprensa (Levine, 1982, p. 25). Nesta fase, o estilo de jogo era essencialmente ofensivo, tendo o ataque como meta principal, pois a beleza do jogo estava em primeiro lugar. Jogava-se o futebol puro, por simples prazer, um lazer, livre de interesses econômicos. O cenário do futebol era o seguinte:

(...) os rapazes de terno e gravata, as moças com chapéus e flores. Os jogadores eram sócios dos clubes e freqüentavam suas festas e bailes. Os filhos jogavam, as filhas e os pais ficavam na tribuna: os 'grandes' clubes de futebol - o Botafogo, campeão de 1914 e 1915, o América, campeão de 1916, o Fluminense, tricampeão de 1917, 1918 e 1919 - eram uma segunda casa para essas boas famílias. Uma diferença social fazia-se sentir nos encontros entre 'grandes' e 'pequenos' clubes, mas era visto como normal o confronto entre clubes provenientes das diferentes fontes 'inglesas' de introdução do futebol (Lopes, 1994a, p. 70).

O amadorismo vigorou como concepção de prática esportiva preferida pela aristocracia, herança da classe dos lazeres de uma elite inglesa. $\mathrm{O}$ futebol era praticado por jogadores originários da elite, ligados às escolas ou 
às empresas e por alguns atletas operários de determinadas empresas.

O racismo predominou por muito tempo, proibindo negros na seleção brasileira e em vários times. O racismo no futebol brasileiro pode ser percebido se tomarmos o exemplo da seleção brasileira de 1919, formada apenas por jogadores brancos, pois o então presidente Epitácio Pessoa proibia a convocação de jogadores negros (Caldas, 1990, p. 102).

Este período coincide com o futebol de fábricas, no qual o futebol era usado como mecanismo de diversão e disciplina para os trabalhadores, bem como veículo publicitário importante na divulgação da imagem e prestígio das empresas (Antunes, 1994, p. 106-107). O que melhor define esta fase é o amadorismo "(...) herdado da concepção aristocrática de uma prática esportiva oriunda da classe dos lazeres, vinda da Inglaterra e reservada a uma elite, e o esporte 'paternalista', representado pelas equipes de empresas" (Lopes, 1994a, p. 66). Este período inclui ainda a famosa fase da clandestinidade e da inserção de negros no futebol. Marca também os anos românticos e o falso amadorismo.

A partir de 1917, começou a cobrança de ingressos no futebol de São Paulo e do Rio de Janeiro. A finalidade do dinheiro consistia em cobrir custos com bolas, uniformes, chuteiras e, posteriormente, pagamento de salários dos atletas. A revolução vascaína no Rio de Janeiro, em 1923, configura-se como acontecimento fundamental no processo de popularização do futebol no Brasil. O Clube de Regatas Vasco da Gama contribuiu com o processo de democratização no futebol brasileiro quando venceu o campeonato carioca de 1932, com uma equipe formada basicamente por jogadores negros, mulatos ou brancos pobres. Tal fato representou "(...) muita humiIhação para os times grã-finos, cujos times eram formados, em sua grande maioria, por jovens estudantes e profissionais de alto nível da elite carioca" (Caldas, 1990, p. 44). Considerando o contexto elitista no qual o futebol estava inserido, podemos sugerir a tese de que a conquista vascaína representou uma vitória popular no futebol carioca diante do elitismo do Flamengo, 
Fluminense e Botafogo.

\subsection{Democratização e profissionalismo no futebol}

A fase do início do profissionalismo, datada, na literatura oficial, de 1933 a 1950, caracteriza-se pela regulamentação do futebol como profissão através da legislação social e trabalhista do governo Vargas (1930-1936). É nas primeiras décadas do século XX que começa a popularização do futebol. Sua democratização e consagração como elemento da cultura nacional se dá a partir dos anos 1930, tendo como marco a implementação do regime profissional em 1933 (Moura, 1998, p. 19).

A passagem do amadorismo para o futebol profissional é marcada pela entrada em cena de jogadores de origens populares nos grandes clubes, apesar dos obstáculos quase instransponíveis que tiveram que enfrentar. Os jogadores negros e mestiços são os pioneiros no que viria a ser conhecido como o estilo brasileiro de jogar futebol, segundo as elaborações de Freyre (1971, 1964) e Rodrigues Filho (1964). Esses serão os atletas socialmente identificados como os criadores e a razão de ser do chamado futebol-arte, uma das peculiaridades brasileiras nesse esporte (Lopes, 1998, p. 19). Segundo a narrativa que domina o imaginário social sobre o futebol, a forma espontânea de jogar caracterizada pela astúcia, criatividade e improviso nos diferenciaria dos países europeus. Essa técnica futebolística (a ginga brasileira) seria considerada um elemento importante na construção da identidade nacional.

O leitor deve ter em mente que o processo de democratização funcional do futebol, ${ }^{6}$ identificado à aceitação de jogadores mestiços e negros nessa modalidade esportiva, não necessariamente teve início no período datado acima. Pois basta lembrar o caso do Vasco da Gama, equipe campeã do campeonato do Rio de Janeiro em 1923, sendo formada basicamente por negros.

O profissionalismo possibilita a inserção de atletas mestiços, negros e

6 Democratização funcional significa também que a elite dirigente migra da prática futebolística para organização e direção dos clubes. Com isso, muda-se o perfil dos praticantes do futebol. Para uma análise mais acurada da democratização funcional do futebol brasileiro, ver Damo (2002). 
mulatos nos grandes clubes, sem que sejam considerados critérios sociais ou étnicos. A técnica torna-se o critério mais importante na seleção de atletas. Os jogadores de cor são aceitos no clube, porém sem participar da vida social, criando-se uma nítida divisão entre o campo de futebol e o clube (Rosenfeld, 1993, p. 87). É neste sentido que podem ser articulados dois aspectos simultâneos no futebol dentro do período considerado: profissionalismo e democratização. A conversão do futebol em trabalho, conseqüência direta da profissionalização, significa a abertura de um canal de emancipação social de negros, mulatos e brancos pobres.

O futebol torna-se espetáculo de massa. Trata-se do processo de transição do elitismo à popularização do futebol brasileiro. É nesta fase que o Brasil cria seus primeiros mitos futebolísticos. Por exemplo, Friedenreich, moreno que se tornou herói nacional ao marcar o gol da vitória brasileira contra o Uruguai em 1919. Estava aberto um dos caminhos na democratização e popularização do futebol. Outros ídolos de cor foram Leônidas da Silva, Domingos da Guia, que, de certa forma, encarnaram a ideologia da "democracia racial", tão contestada posteriormente.

\subsection{Consagração do "estilo brasileiro" de jogar futebol}

O futebol tem regras universais, mas é adaptado aos países de forma peculiar. As diferenças que mais tarde viriam marcar o estilo brasileiro de jogar futebol começam a se tornar explícitas a partir da década de 30, não apenas através da participação brasileira nas Copas do Mundo, mas também, quando times nacionais enfrentavam equipes estrangeiras, seja no Brasil ou no exterior.

A fase da consagração teve início na década de 50 e se consolidou nos anos 70. No Mundial de 1950, o Brasil apresentou um belo estilo de jogo, terminou a competição em segundo lugar, consolidando seu estilo de jogar futebol, tendo como arquitetos os jogadores negros e mulatos. Segundo Rodrigues Filho (1964), foi o futebol-arte, feito de magia, ginga e impro- 
viso que constrói a identidade nacional, tendo Leônidas, Domingos e Fausto como principais expressões. Na verdade, esta visão de que os negros foram os principais arquitetos do futebol-arte deve ser analisada cuidadosamente. Deve-se ter em conta que, desde a implementação do regime profissional no futebol nos anos 30, que os negros e mulatos tornam-se maioria entre os jogadores; em praticamente todos os clubes o maior número de jogadores é formado por negros e mulatos.

Acerca do estilo brasileiro de jogar futebol, pode-se aludir à narrativa de Lopes (1994a, p. 76):

(...) em que ele pode melhor aparecer e caracterizar-se através da criação de jogadas... talvez a caracterização desse estilo torne-se mais visivel tal qual ele se incorporou no jogo mais 'lento' e 'cerebral' do meio campo Didi (eleito o melhor jogador da copa de 1958 pela crônica esportiva internacional): não somente ele é o inventor do chute a gol denominado 'folha seca', mas também a sua postura corporal ereta, seus dribles de corpo sutis e seus passes e lançamentos a longa distância 'de curva', que resultam em um estilo de jogo do menor esforço aparente, do uso da inteligência e da astúcia mais que da força.

Na verdade, esse estilo se configura no chamado "futebol-arte", caracterizado especialmente pela astúcia, improviso, elasticidade, individualidade e capacidade de criação. Há quem atribua tal estilo à nossa formação étnico-cultural. É o caso de Freyre $(1971,1964)$, para quem o futebol brasileiro expressa a mulatice e a brasilidade. A mistura das três raças seria responsável pela ginga de nossos atletas dentro de campo, fundando um estilo próprio de jogar futebol.

No entanto, deve-se considerar que algumas narrativas acerca da forma brasileira de jogar futebol são essencialmente míticas, verdadeiras visões românticas sobre o futebol e a cultura brasileira. Isso pode ser explica- 
do pelo fato de seus maiores expoentes serem apaixonados pelos seus objetos. No caso de Rodrigues Filho (1964), trata-se de um jornalista diretamente envolvido na produção do espetáculo futebolístico, preocupado em explicitar as características positivas do futebol e do negro brasileiro. Sua obra faz uma apologia ao papel do negro no futebol nacional: por isso merece ser analisada criticamente.

Já Freyre $(1971,1964)$, como se sabe, muito se preocupou com a identidade nacional. Em vários momentos de sua obra, percebem-se tentativas de valorização do negro na formação social e cultural brasileira. Sua explicação para o estilo brasileiro de jogar futebol como produto do mulato e do negro necessita de acabamentos. Talvez possamos acrescentar mais dois fatores: o racismo e a má interpretação das regras do futebol no Brasil contribuíram também para se criar um estilo de jogar futebol genuíno, tipicamente brasileiro. $\mathrm{O}$ racismo no futebol exigia dos negros e mulatos o intenso cuidado em desviar, não tocar em jogadores brancos, pois em alguns casos, isso poderia provocar agressões. A constante exigência de dribles e habilidades dos jogadores de cor foi essencializando uma forma de prática futebolística baseada na ginga, habilidade e talento. Na verdade, isso teve sua contribuição para o futebol-arte.

Quanto ao segundo fator, a má interpretação das regras universais do futebol no Brasil, podemos referir aqui a tese de Toledo (2002). Este autor defende que os brasileiros inicialmente interpretaram mal as regras do futebol. Isso teria contribuído para que o contato corpo a corpo e o tranco fossem tidos como irregularidades, algo para ser evitado no Brasil: por isso, nossa habilidade em dribles geniais, ginga, firulas e plasticidade nas jogadas. Portanto, parece sensato o argumento de Toledo, segundo o qual a má interpretação das regras do futebol teve influência na construção social de um estilo brasileiro de jogar futebol, bastante diferente do futebol praticado nos outros países onde o tranco e o jogo corpo-a-corpo são típicos e nunca foram interpretados como irregulares. 
Para sintetizar esta brevíssima abordagem do processo de construção do estilo brasileiro, é necessário apontar traços que marcam a diferenciação entre futebol brasileiro e futebol europeu. O futebol brasileiro é intuitivo, artístico, espetáculo, natureza, individual, dom, agilidade, habilidade, malandro, improvisado, jogo, dionisíaco, barroco, futebol-arte. Por outro lado, o futebol europeu é racional, eficiência, competitivo, cultura, coletivo, aprendizado, rigidez, força, apolíneo, clássico, escola, futebol-força (Damo, 2002, p. 125).

O estilo brasileiro de jogar entra em crise a partir das últimas décadas do século XX, quando o processo de modernização e comercialização do espetáculo futebolístico implica a necessidade cada vez maior de vitórias. É necessário mudar-se a forma de jogar futebol, adotar um futebol mais competitivo, baseado na aplicação tática e na preparação física, em detrimento da habilidade, magia, ginga. A preparação física é intensificada, formando jogadores mais fortes do que habilidosos. O polêmico debate entre futebolarte e futebol-força divide os especialistas no assunto, criando correntes antagônicas: (a) futebol-arte, liderada por João Saldanha, e (b) futebol-força, moderno, liderada por Cláudio Coutinho e Carlos Alberto Parreira (Gil, 1994).

\subsection{Modernização e comercialização do futebol}

Desejamos acrescentar uma outra fase: a da modernização, podendo ser datada de 1970 aos nossos dias. Caracteriza-se pelo crescimento de recursos financeiros no futebol, televisionamento das partidas ao vivo, crescimento no nível salarial dos jogadores e do êxodo de jogadores brasileiros para o futebol europeu, nas últimas décadas do século XX. O surgimento do Clube dos Treze, a Lei Zico, a Lei Pelé e o fim do passe são elementos que marcam esse momento do futebol brasileiro.

A modernização do futebol possibilitou a comercialização do espetáculo futebolístico, a introdução da publicidade ao redor do gramado, nas camisas dos times e o televisionamento ao vivo de partidas de futebol. A mudança no estilo brasileiro de jogar tornou-se mais evidente nesse período, especial- 
mente quando os clubes e a seleção nacional adotaram novos métodos de treinamento, dando ênfase à preparação física e à armação tática da equipe em campo. Podemos aludir aqui ao futebol-força, ou futebol científico, ambos conseqüências da crescente comercialização do futebol, que foram adotados no Brasil pela maioria dos clubes. No entanto não estamos julgando o futebol-força, mas entendemos este como uma necessidade colocada pela modernização do futebol em nível mundial.

Com a finalidade de orientar melhor o leitor, apresentamos um quadro que caracteriza de modo sucinto o desenvolvimento do futebol no Brasil. Quadro 1. Mapa Histórico-Sociológico do Futebol Brasileiro

\begin{tabular}{|c|c|c|}
\hline Fase & Período & Caracterização \\
\hline Os primeiros tempos & 1894-1905 & $\begin{array}{l}\text { Clubes urbanos } \\
\text {. Futebol nas escolas de elite } \\
\text {. Incentivo da Igreja } \\
\text {. Futebol de fábrica } \\
\text {. Diversão e disciplinamento da }\end{array}$ \\
\hline Amadorismo aristocrático & 1905-1933 & $\begin{array}{l}\text { juventude aristocrática } \\
\text {.Elitismo } \\
\text {.Racismo } \\
\text {.A divulgação na imprensa } \\
\text {.Disciplinamento de operários } \\
\text {.Profissionalismo "marrom" } \\
\text {.Revolução vascaína }\end{array}$ \\
\hline $\begin{array}{l}\text { Democratização e } \\
\text { profissionalismo }\end{array}$ & $1933-1950$ & $\begin{array}{l}\text { Popularização do futebol } \\
\text {.Profissionalização } \\
\text {.Democracia racial } \\
\text {.Futebol-arte }\end{array}$ \\
\hline $\begin{array}{l}\text { Consagração do estilo } \\
\text { brasileiro }\end{array}$ & $1950-1970$ & $\begin{array}{l}\text {.Reconhecimento internacional } \\
. \text { A conquista das copas (1958, } 62 \text { e } 70)\end{array}$ \\
\hline $\begin{array}{l}\text { Modernização e } \\
\text { comercialização }\end{array}$ & 1970-2002 & $\begin{array}{l}\text {.Comercialização } \\
\text {.Publicidade } \\
\text {.A TV } \\
\text {.Futebol-força } \\
\text {.Os CTS } \\
\text {.As conquistas do Tetra (1994) e do } \\
\text { Penta (2002) }\end{array}$ \\
\hline
\end{tabular}




\section{Modernização no futebol brasileiro: a intervenção científica na formação do jogador de futebol nos anos 90}

\subsection{O advento dos Centros de Treinamentos no futebol brasileiro}

No Brasil, os Centros de Treinamentos fazem parte de um movimento de modernização dos clubes, iniciado na década de 80. Trata-se de uma tentativa de formar novos jogadores no Brasil, o que revela um alinhamento com os padrões de formação no futebol mundial, padronizando os métodos e técnicas. Estes são elementos da modernização pela qual passa o nosso futebol, e foram proporcionados por parcerias entre os clubes e as empresas. Pode-se pensar esses centros como verdadeiros laboratórios de formação e preparação de atletas, implementando uma nova concepção de futebol competitivo, na qual a preparação física e tática ganha relevo especial.

Os $\mathrm{CTs}^{7}$ utilizam tecnologias e valorizam conhecimentos científicos e novos profissionais, como preparadores físicos, fisiologistas, supervisores, nutricionistas, psicólogos e outros na formação de atletas, o que até então era desprezado no Brasil. De fato,

os CTs consistem, portanto, em laboratórios de novos projetos que atendam a uma escala mais ampliada de formação, preparação, competitividade e negociação de atletas, preferencialmente para o Exterior, contemplando uma demanda internacionalizada de circulação no mercado de jogadores (Toledo, 2002, p. 136).

Entre as virtudes dos atletas fabricados em CTs estão: disciplina, pontualidade, capacidade de adaptação, técnica, preparação física. ${ }^{8}$ A disciplina deve-se, em parte, ao confinamento do atleta numa estrutura especial-

7 CTs de agora em diante, utilizaremos esta sigla para referir os Centros de Treinamentos.

8 Os CTs, favorecendo a valorização da preparação física no futebol brasileiro, promoveram maior reconhecimento e prestígio dentro do cenário futebolístico aos preparadores físicos, igualando-se até mesmo a determinados jogadores e técnicos. Um dos profissionais mais valorizados nesta área é Moraci Sant'Anna, que trabalhou com Telê Santana no São Paulo, quando foi bicampeão da Taça Libertadores e do Mundial Interclubes em 1992 e 1993. Trabalhou ainda com Carlos Alberto Parreira pela seleção brasileira na Copa do Mundo de 1994. 
mente voltada para tal fim, além de seguir uma rigorosa rotina de treinamentos, testes, preparação física e reparações médicas. Os CTs separam os atletas do mundo exterior. Trata-se de um regime militar adaptado ao futebol, no qual o disciplinamento dá-se também através de multas para coibir os atrasos e faltas aos treinos. Os clubes, como São Paulo, Palmeiras, SC Internacional e outros, utilizam manuais de conduta, cartilhas de comportamento. As inovações advindas do trabalho nos CTs são formas de atender necessidades do futebol moderno, competitivo e altamente comercializado, por isso, cumprem funções positivas.

As mudanças no futebol implicaram a necessidade de novas pedagogias na formação de atletas e no condicionamento tático. Tais pedagogias proporcionariam, além do adestramento e manutenção do preparo técnico, físico e moral dos jogadores, ciclos mais abstratos e sistematizados de assimilação da técnica, bem como mecanismos capazes de incrementar a capacidade de aprendizagem do atleta. Entre as inovações que as novas pedagogias possibilitaram estão: gravação de treinamentos, avaliação individual do atleta, cine-vídeo, treinos com paredão metálico, com viseiras, metodologias informacionais, jogos virtuais. Isso implica uma formação mais ampla do atleta, diga-se, globalista. Tal perspectiva fundamenta o trabalho adotado no SC Internacional a partir de 1997, quando ocorreu uma reformulação do departamento de futebol e nova integração entre os setores ligados à formação de jogadores, bem como uma maior intervenção científica nos treinamentos e na preparação dos atletas. Algo semelhante havia acontecido em outros grandes clubes brasileiros, como no São Paulo, ainda na década de 1980.

No caso do São Paulo, o movimento de transformação do departamento de futebol em laboratório de fabricação de jogadores, data de 1986, momento no qual se passa a utilizar a medicina especializada e a fisiologia do esforço. Segundo o administrador do futebol profissional do São Paulo, Marco Aurélio Cunha: “(..) daquele trabalho agregado entre departamento 
médico e comissão técnica, todos agindo com um instrumental fundamental, os dados da fisiologia, 'nasce', entre outros meninos então franzinos, craques como Cafu, Muller, Juninho (...)" (A Gazeta Esportiva, 16/11/1986; 23/01/1997).

A década de 90 marca a consolidação do modelo jogador-máquina, produto do esquadrinhamento do corpo do atleta por intermédio da ciência esportiva. Talvez o maior exemplo desse tipo de atleta seja Ronaldo Nazário, o Ronaldinho, goleador do campeonato mundial de 2002. Trata-se de um jogador criado na era do computador, pois, "com ajuda de um aparelho de musculação informatizado (ele) mudou por completo sua força física nos últimos dois anos: passou de 76 para 80 quilos e cresceu de 1,76m para 1,82m" (O Globo, 20/02/96). O jogador-máquina é normal, paciente e não se mete em confusões, obediente aos esquemas táticos. Rivaldo é exemplo de jogador moderno: marca, ataca e faz gols, atende os esquemas, é disciplinado. O advento deste tipo de jogador é mais uma faceta da modernidade no futebol brasileiro.

O São Paulo adotou procedimentos de avaliação dos jogadores, medição do rendimento, capacidade e como adequar seus jogadores ao estilo do técnico. Utilizou a filmagem de treinos e jogos, criando um trabalho de laboratório. Tudo isso aconteceu no SC Internacional com Medina pós-1997 (Rodrigues, 2003).

\subsection{Manuais de conduta e a cartilha do jogador disciplinar}

A cartilha do jogador-disciplinar assume um novo papel a partir dos anos 90, quando se estabelece uma fase punitiva no futebol brasileiro. Clubes importantes criaram modelos para disciplinar seus atletas, buscando construir um jogador adequado aos novos tempos do futebol moderno, competitivo, profissional e disciplinar. O São Paulo criou um código de conduta, o Flamengo prima pela disciplina, o Palmeiras é linha-dura. O futebol-empresa fundamenta-se no modelo de empresa-militarizada. A busca pela disciplina parece 
ir ao encontro da profissionalização do futebol, em que um ascetismo profissional é cada vez mais reivindicado. Neste processo, não só o trabalho, mas a vida do atleta é gerida pelo clube (Florenzano, 1998, p. 168).

O São Paulo adota a cartilha de conduta para normalizar o comportamento de seus jogadores. Até mesmo técnicos como Telê Santana passam a optar pela Cartilha disciplinar. O técnico afirmava que "Os jogadores serão mais cobrados. Serão tratados como verdadeiros profissionais, como em uma empresa" (Folha de São Paulo, 09/01/1996, Esportes, p. 1). A cartilha disciplinar do São Paulo versa que

(...) o jogador do São Paulo está proibido de praticar atividades esportivas que não seja o futebol; é proibido jogar cartas ou qualquer jogo de azar dentro das instalações do clube; é proibido freqüentar boates e dancings nas horas de folga; é proibido comer na sala de televisão; é proibido entrar no CCT depois da meia-noite; é proibida a prática de cultos religiosos no clube; o atleta do São Paulo não pode ingerir bebidas alcoólicas (Diário Popular, 09/01/1996, Esportes, p. 1).

De fato, essa cartilha indica o nível de controle e disciplina que o clube mantém sobre os jogadores, algo que transcende ao futebol, interferindo diretamente na vida pessoal. Na linguagem de Foucault (1987, p. 159), este poder seria instrumento de disciplinação, algo no sentido de sanção normalizadora, ou seja, "(...) entendida como um conjunto de procedimentos punitivos relacionados a uma infinidade de pequenas atitudes e comportamentos (e que) incide sobre um espaço deixado pelas leis". São parte do sistema disciplinar do novo futebol, no qual os gestos, falas, comportamentos, corpo, atitudes são objetos controlados e passíveis de punição. ${ }^{9}$

No caso do Palmeiras, o técnico Luxemburgo adota linha-dura em 1996, afirmando que os atletas deverão sacrificar a vida pessoal e entrar na

9 Sobre punições aos gestos dos atletas, vale lembrar a punição aplicada ao jogador Belleti do São Paulo, em 25\% de multa no salário por criticar o técnico do time em 1996, Carlos Alberto Parreira (Florenzano, 1998, p. 170-171). 
filosofia do clube. Nossa crítica se dirige ao controle demasiado sobre a individualidade do atleta e não exatamente ao disciplinamento necessário ao exercício da profissão.

No Corinthians, a cartilha defendia que o atleta não podia beber nem fumar, devia usar obrigatoriamente o uniforme de viagem e, sempre que atrasasse em treinos e viagens, haveria punições. Haveria ainda punição para o atleta que recebesse cartão amarelo por reclamação ao árbitro, podendo até ser multado.

O poder investido sobre o atleta brasileiro nos anos 90 tinha como objetivo fabricar um novo trabalhador, enquadrar nossos atletas no modelo de futebol moderno, internalizar novos comportamentos, dentro de doutrinas produtivas ao clube. ${ }^{10} \mathrm{O}$ futebol moderno, modelo empresa parece, em nome do profissionalismo, buscar o controle da vida do atleta, dentro e fora dos gramados.

\section{Modernização e futebol científico no SC Internacional: a década de 90}

A modernização do departamento de futebol do SC Internacional teve como base inicial a criação de alguns projetos importantes como: (1) Modernização e remodelação de toda a estrutura do departamento de futebol; (2) Criação do Internacional Data Center (Intercenter), uma rede de informática com 14 computadores no Beira-Rio, contendo programas específicos para o futebol, como jogos virtuais, modelos de técnicas, esquemas táticos, simulações de jogadas; (3) Criação do departamento de psicologia e pedagogia; (4) Cine-vídeo; (5) Construção de módulos de treinamentos específicos para as categorias de base; (6) Promoção de palestras com especialistas em futebol (técnico, atleta, pesquisador etc.) para os jogadores

10 Neste sentido, é ilustrativo o fato de que assim, “Luxemburgo prega disciplina. Diz que o jogador de futebol brasileiro é maleducado e que necessita se adaptar a nova realidade [...] O treinador palmeirense diz também que está sendo muito difícil doutrinar os atletas" (A Gazeta esportiva, 17/10/1996, p. 5). 
das categorias de base; (7) Programa de integração entre as categorias inferiores e profissional; (8) Criação de um modelo tático único para todas as categorias de base até os profissionais (Rodrigues, 2003). ${ }^{11}$

\subsection{Novas técnicas de treinamento}

Ao elaborar novos módulos de treinamento para aplicar no SC Internacional, Medina consultou jogadores consagrados e especialistas em chutes fortes e de efeito, como Rivelino e Neto, visando aperfeiçoar as técnicas de chute. Utilizou também métodos de treinamentos de outros esportes coletivos. Em 1994, Telê Santana auxiliou Medina a desenvolver a técnica de treinamento que utiliza uma cesta para ensinar e aperfeiçoar lançamentos, visando melhorar a precisão de passes e lançamentos de longa distância. O treino com a cesta utiliza-se ainda do paredão metálico que consiste basicamente em "(...) uma espécie de paredão metálico com várias marcações e uma cesta. O jogador deve acertar as marcas na parede ou tentar colocar a bola na cesta, para aprimorar a precisão dos lançamentos" (Zero Hora, 17/05/1997, Esportes, p. 6). Esta técnica consiste em colocar cesta a certas distâncias e ordenar que os jogadores lancem bolas tentando acertá-las dentro da cesta. Com esta técnica, Telê Santana ensinou lançamentos a Raí, Palhinha, Juninho Paulista, Muller e outros grandes atletas.

O treinador Guto Ferreira trouxe para o SC Internacional outros métodos de treinamento utilizados no basquete, que havia adotado quando trabalhava no São Paulo Futebol Clube. É evidente a influência de Telê Santana e Medina no trabalho de Guto. Por exemplo, o uso de viseiras no rosto dos atletas com a finalidade de impedir que os mesmos olhassem para o chão. Esta técnica era comum nos treinos da equipe feminina de basquete do BCN de Piracicaba - SP. Segundo Guto, essa técnica tem o propósito de melhorar o controle de bola, sem necessidade de o jogador olhar para o chão, dando, conseqüentemente, mais velocidade ao time e dinâmica ao

11 Sobre a modernização no SC Internacional, ver especialmente os capítulos 4 e 5 do trabalho de Rodrigues (2003). 
jogo. Segundo Corrêa (Zero Hora, 17/05/1997, p.6), estas formas de treinamento significam a implantação de modelos de treinamento para desenvolver os fundamentos do futebol nas categorias de base, sendo mais um passo na consolidação do futebol científico no Beira-Rio. Neste sentido,

A idéia de utilizar viseiras entre os garotos faz parte da reformulação nos métodos de formação de jogadores no Estádio Beira-Rio. Chefiados pelo Coordenador João Paulo Medina, os treinadores das categorias inferiores procuraram desde o início do ano novas técnicas pedagógicas para o desenvolvimento de fundamentos como o passe, o lançamento e o chute a gol (Zero Hora, 17/05/1997, p.06).

A necessidade de modernizar o treinamento está em consonância com a produção social de um jogador de futebol moderno, para preencher as demandas criadas pelo futebol atual. Como afirmava Medina, "Temos que modernizar os treinos nas divisões de base. Não é mais possível usarmos as mesmas técnicas de décadas atrás" (Zero Hora, 17/05/1997, p. 6). Dentro desta nova perspectiva de formação de jogadores, orientada pela teoria globalista, a polivalência é um dos princípios norteadores. O coordenador Medina ressaltava que, nas categorias de base do SC Internacional, o lateral que não souber cruzar, o centroavante que cabeceia mal e o meia que lança com defeitos estavam com os dias contados. Ao lateral, é ensinado defender e atacar, cruzar e marcar. Ao centroavante, é cobrado que faça gols de chutes e cabeceios, bem como até mesmo contribuir com o meio-campo na marcação. Portanto, as funções se diversificaram no futebol moderno, especialmente no momento de competições acirradas e altamente comercializadas.

Além das técnicas já referidas, adotou-se uma forma de adaptar o atleta, desde sua formação, à pressão da torcida adversária, na tentativa de internalizar e naturalizar essa pressão na consciência do atleta. Assim, estudaram métodos de treinamento da seleção russa de vôlei masculino, que treinava ao som potente de alto-falantes com gravações de xingamentos e 
vaias de torcidas adversárias. Isso faz com que os jogadores se acostumem ao barulho das vaias de torcidas, passando a encará-las com naturalidade. Tal técnica também foi adotada no SC Internacional, com bons resultados.

\section{Motivação profissional, sacrifícios e disciplinamento do jogador de futebol no SC Internacional}

\subsection{Motivação profissional}

Analisaremos, nesta parte do trabalho, as fontes sociais das motivações profissionais dos jogadores. A crença no dom para ser jogador de futebol, a esperança em enriquecer através do futebol, a família e a seleção brasileira são motivadores dos jogadores para o futebol.

Tabela 1. Motivação pelo futebol

\begin{tabular}{c|c|c}
\hline Motivação & Frequency & Percent \\
\hline Dom & 28 & 50,0 \\
\hline Enriquecer & 12 & 21,4 \\
\hline Incentivo da família & 08 & 14,3 \\
\hline Seleção brasileira & 06 & 10,7 \\
\hline NS/NR & 02 & 3,6 \\
\hline Total & 56 & 100,0 \\
\hline
\end{tabular}

Fonte: Rodrigues (2003, pp. 145-147)

A tabela 1 apresenta a distribuição da motivação profissional dos atletas pesquisados. A pergunta colocada era a seguinte: Por que escolheu o futebol como profissão? 21,4\% dos atletas escolheram o futebol porque pretendem enriquecer através dele. Este grupo representa atletas que têm um projeto de vida baseado no cálculo, acreditando que o futebol é o canal mais adequado para realizá-lo. Isso se deve, em parte, ao discurso dominante na sociedade, muito reforçado pela mídia, de que o futebol é um ótimo 
canal de ascensão social, bem como uma das profissões que oferece meIhores salários. Isso deve ser analisado criteriosamente, pois a percentagem de atletas que recebem salários elevados é mínima no futebol brasileiro.

A motivação material, ou seja, prêmios, bichos e dinheiro, significa motivação extrínseca, aquela que vem de fora do indivíduo, sendo, antes de tudo, uma construção social. Neste tipo se insere o dinheiro, a fama, os prêmios e outras recompensas.

O incentivo da família aparece como terceiro fator mais importante, com $14,3 \%$. Neste caso, o futebol como profissão é um projeto mais amplo, representa a possibilidade de mobilidade social para toda a família, e não apenas para o atleta. Outros estudos apontam esta tendência e a relevância da família como estímulo ao futebol (Araújo, 1980).

A seleção brasileira aparece como motivação para o futebol para 10,7\% dos pesquisados. Entre estes, além do valor simbólico que é representar a pátria através da seleção, está a possibilidade de valorização do passe e do salário. Jogar na seleção significa exposição no mercado futebolístico e, conseqüentemente, a ampliação do mercado de trabalho.

A crença no dom para ser jogador de futebol é o principal motivador dos atletas entrevistados, aparecendo com $50 \%$. Trata-se da chamada motivação intrínseca, aquela que vem de dentro do atleta, sendo, por isso, a mais original e valorizada pelos técnicos e professores que trabalham nas categorias de base do SC Internacional. Quando perguntamos a um atleta por que ele deseja ser jogador de futebol, sua resposta foi: "Todo mundo tem essa vontade de ser jogador de futebol. É um sonho de muitos garotos. Além da vontade, Deus me deu o dom. Eu exerço esta profissão porque gosto mesmo". Nesta mesma entrevista, perguntado sobre a orientação profissional que teve, afirmou: "Sempre tive vontade própria de ser jogador, mas a família me incentivou muito" (Atleta, 02).

Entretanto, pode-se cogitar que o dom indica atributos naturais para esta atividade, bem como eventual existência de uma "vocação" para o 
futebol. Este tem um valor em si, é uma causa, uma fonte de realização. Neste sentido, seria conveniente traçar um paralelo, se houvesse espaço neste trabalho, entre a vocação para o futebol (do jovem brasileiro) e a vocação do jovem cientista na Alemanha e nos Estados Unidos, tomando como referência o trabalho de Weber (1968, p. 23), para quem certas características do cientista, dependem também "(...) - de um dom pessoal e de maneira alguma se confunde com os conhecimentos científicos de que seja possuidora uma pessoa".

A vocação para determinadas áreas faz com que o sujeito vocacionado viva somente para sua vocação, atropelando sua vida pessoal, não apenas no momento de formação (Weber, 1968, p. 24). Como ressalta Weber, há grandes prejuízos para a vida interior do cientista. Tal fato se reflete na formação e vida do jogador de futebol, no qual a vida das pessoas é sacrificada desde cedo. Os jogadores revelaram, na pesquisa, que os principais sacrifícios são renunciar à vida pessoal, as concentrações e os treinamentos excessivos. Esta vocação indica que a profissão tem um valor em si, proporciona sentido, auto-realização, algo muito mais do que a remuneração. É assim que podemos entender os motivos pelos quais jovens se dedicam ao futebol e à ciência, além de outros ofícios.

\subsection{Disciplinamento do jogador de futebol}

Um dos fios condutores deste trabalho é a idéia de que a formação do jogador de futebol consiste em um processo de disciplinamento que é paradoxalmente repressivo e civilizatório. Constitui um contínuo processo de aquisição de técnicas, conhecimentos e habilidades. Tal disciplinamento também é encontrado em outras modalidades esportivas. No entanto interessa-nos aqui destacar as especificidades dos mecanismos de disciplinamento utilizados no futebol moderno, tendo como base empírica o SC Internacional.

Primeiro, observemos os dados na tabela 2. 
Tabela 2. Mecanismos de disciplinamento

\begin{tabular}{c|c|c}
\hline Mecanismo de disciplinamento & Frequency & Percent \\
\hline Controle Social & 34 & 60,7 \\
\hline Treinamentos & 14 & 25,0 \\
\hline Repressão & 8 & 14,3 \\
\hline Total & 56 & 100,0 \\
\hline
\end{tabular}

Fonte: Rodrigues (2003, p. 156).

Tomando como base a concepção dos jogadores sobre os principais mecanismos que disciplinam e, ao mesmo tempo, produzem e modelam os corpos dos jogadores, pode-se observar que o controle social é o principal dispositivo de disciplinamento. Isso para $60,7 \%$ dos atletas. Por controle social entendam-se regras e normas inerentes à organização do clube, horário de atividades, proibições de sair à noite, de dar entrevistas sem autorização, além de outras questões. Com isso, podemos cogitar que o atleta é controlado pelo clube, sendo subordinado aos interesses maiores. O controle do clube sobre o atleta quando do processo de disciplinamento do corpo para o exercício das atividades futebolísticas é inerente à preparação dos atletas para o esporte profissional (caracteriza-se pela racionalização, seriedade, competitividade, erosão da dimensão lúdica e busca por resultados), algo presente em outras modalidades esportivas, e tem como finalidade tornar os atletas aptos para atuar na sua vida profissional. Não temos nada contra este tipo de preparação física, técnica e profissional. A nossa crítica se estende particularmente ao fato de o poder disciplinar e o controle social presente no futebol moderno transcender ao futebol. Ou seja, os atletas são objetos dos clubes, controlados dentro e fora do futebol. Muitos atletas têm sua vida social totalmente organizada em função dos interesses dos clubes, o que muitas vezes implica prejuízos para a vida pessoal. 
O conjunto de treinamentos físicos, técnicos e táticos é outro mecanismo disciplinador, sendo o principal para $25 \%$ dos entrevistados. Tratase de uma preparação e formação do corpo do atleta para render o máximo em campo, tornando o corpo dócil e rentável em termos econômicos. Aqui podemos fazer alusão à abordagem de Foucault $(1989,1987)$ acerca da docilidade de corpo moderno. Os treinamentos objetivam colocar o atleta em "forma", aumentar o rendimento do jogador em campo, tornando-o mais produtivo. Estes tipos de treinamento são mecanismos disciplinares que constituem o cerne da formação profissional do jogador de futebol, são aspectos civilizadores, pois significam internalizar normas, regras e formas de ação. O esporte, em Elias (1992), também tem função disciplinar, contribui com a formação de uma conduta nova, marcada pelo autocontrole. Elias concebe o processo civilizador de forma positiva, algo gerador da multiplicação e expansão do autocontrole e do controle social. Civilização como adestramento e pacificação dos costumes.

A repressão é o terceiro mecanismo de disciplinamento, sendo o primeiro para 14,3\% dos atletas. Cabe aqui especificar melhor o que se entende por repressão. Trata-se de punições. Estas geralmente são sanções diretas, como multas por atrasos aos treinos, multas quando o atleta recebe o terceiro cartão amarelo sem justificativa ou é expulso. Entre as punições está também o afastamento do grupo, colocar o jogador para treinar separado. $\mathrm{O}$ banco de reservas pode ser um tipo punição, às vezes, quando o jogador se desentende com o técnico ou quando não consegue render o esperado.

O processo de disciplinamento ao qual está submetido o atleta se reveste de um poder (Foucault, 2001 e 1987) positivo que produz o jogador desejado pelo clube, ao mesmo tempo em que forma um cidadão dotado de comportamento altamente regulamentado. A internalização de regras, esquemas táticos e normas de conduta implica a construção de um comportamento civilizado (Elias, 1992) do atleta. O atleta é dotado de uma nova sensibilidade com relação às regras futebolísticas e sociais, sendo o autocontrole a principal marca. No caso analisado neste trabalho, 
percebemos que, no SC Internacional, a produção social do jogador de futebol consiste num processo educativo, disciplinador e civilizatório, em que a preocupação com a formação global do atleta é constante. Trata-se de formar jogador polivalente, dotado de visão global do processo e não apenas de sua posição (função) específica.

Podem-se apontar determinadas proximidades e semelhanças entre o processo de formação do sujeito moderno e aquele que é adotado no treinamento do corpo no esporte. Em ambos há sacrifícios. A lógica do sacrifício é compartilhada pelo esporte, podendo ser observada na formação do jogador de futebol e durante o exercício da carreira, pois a tensão entre vida profissional e pessoal é constante nos debates entre jogadores, técnicos e dirigentes.

\subsection{Principais sacrifícios na formação do jogador de futebol}

A formação do jogador de futebol exige sacrifícios. Para uma análise detalhada dos sacrifícios inerentes à profissão de jogador de futebol, sugerimos que o leitor consulte a tabela 3 abaixo:

Tabela 3. Sacrifícios na formação do jogador de futebol

\begin{tabular}{c|c|c}
\hline Sacrifícios & Frequency & Percent \\
\hline Concentrações & 28 & 50,0 \\
\hline Renunciar à vida pessoal & 15 & 26,8 \\
\hline Treinamentos excessivos & 13 & 23,2 \\
\hline Total & 56 & 100,0 \\
\hline
\end{tabular}

Fonte: Rodrigues (2003, p. 154).

A nossa pesquisa revela que os principais sacrifícios na formação do jogador de futebol são as concentrações (50\%), a renúncia à vida pessoal $(26,8 \%)$ e os treinamentos excessivos $(23,2 \%)$. Em relação a este último, 
incluem-se os treinamentos físicos, técnicos e táticos. As concentrações podem ser entendidas como uma forma de controle total do atleta, implicam o domínio do corpo e da alma. O objetivo é deixar os atletas separados do mundo extrafutebol. O futebol moderno exige um ascetismo profissional praticamente religioso, tendo no futebol um fim em si mesmo. É de amplo conhecimento um movimento contestatório da forma de concentração no futebol brasileiro, que surgiu no SC Corinthians Paulista na década de 80, tendo sido liderado por Sócrates, Casagrande ${ }^{12}$ e outros.

A lógica do sacrifício é inerente aos treinamentos esportivos. Nestes, o corpo é visto como um objeto manipulável e operacionalizável, comparável a uma máquina. Então, sendo o corpo comparável a uma máquina, deve-se lembrar que possui peças substituíveis, reparáveis em caso de problemas de funcionamento.

Uma análise profunda desta questão pode levar-nos a entender que o jogador perde parte considerável do controle sobre seu corpo e sua vida, em detrimento do crescimento do controle que os clubes assumem sobre o mesmo. Isso continua sendo substancial, mesmo após a abolição do passe. Pois os treinamentos e as concentrações consomem muito tempo da vida dos jogadores. Portanto, o processo de formação do jogador de futebol é especial, exige um tremendo sacrifício por parte do atleta. Isto precisa ficar evidente para combater discurso do senso comum, segundo o qual a vida de jogador de futebol é moleza, formada por jogos, brincadeiras, apenas por momentos agradáveis. Esses sacrifícios mencionados anteriormente podem ajudar-nos a explicar as razões por que a grande maioria dos jogadores de futebol no Brasil tem origem nas classes menos abastadas, médias e populares. Pois, segundo Medina (2001), os jovens de famílias ricas mostram menos disposição a se submeterem ao conjunto de exercícios, esforços e sacrifícios inerentes ao mundo do futebol, especialmente ao futebol

12 A "Democracia Corinthiana" surgiu numa disputa eleitoral para eleger diretores do clube em 1983, momento anterior à redemocratização brasileira. Os atletas desejavam participar da direção. Sobre este tema, consultar a dissertação de mestrado de SANTOS, L.T. Futebol empresa e a democracia corinthiana: uma administração que deu dribling na crise. Campinas: Unicamp, 1990. 
profissional. Esta tese, para ter credibilidade, requer um estudo empírico mais acurado, o que não pode ser feito nos limites do presente trabalho e nem está dentro dos propósitos no momento.

É importante frisar que a profissão de jogador de futebol exige realmente sacrifícios. Com isso, resta-nos analisar quais seriam os maiores, bem como eles são enfrentados pelos atletas.

É ilustrativo o depoimento de um dos nossos entrevistados. Primeiro, ele afirma:

... acho que o jogador de futebol hoje em dia tem que ser extra-campo muito bem de cabeça, se cuidar, porque como você falou a gente trabalha com o corpo, então se a gente não cuidar dele, se sair a noite, beber e comer coisas ruins, então a gente não vai a lugar nenhum. É preciso um cuidado grande extra-campo para render em campo (Atleta 01).

Isso ilustra um pouco os cuidados com os quais convivem os atletas. Trata-se de um amplo controle social. O futebol demanda uma conduta mais ampla do que as atividades de preparação para o jogo. É um controle da alma e do corpo, tal como lembra Foucault (1987).

Além de sacrifícios, podem-se evocar alguns aspectos educativos do futebol, sendo esta a dimensão que se assume, aqui, como civilizatória. Vejamos a opinião de um atleta sobre isso:

No futebol a gente aprende muito. A gente aprende a obedecer horários certos, comportamentos corretos, então tudo isso nos ensina a gente ser um cara responsável acima de tudo. Então a gente sabe que aqui no Internacional não se forma, não se cria apenas jogador de futebol, mas pessoas com muitas responsabilidades. Cidadãos responsáveis (Atleta, 01).

No processo de formação, os atletas incorporam o conjunto de normas, regras e formas de relações sociais estabelecidas no clube. Neste 
sentido, o futebol é um agente civilizador, pois permite a aprendizagem de maneiras de agir dentro e fora dos campos, implica a construção de novas condutas sociais.

\section{Considerações finais}

Este trabalho investigou a relação entre modernidade, disciplina e formação profissional do jogador de futebol moderno, tendo o SC Internacional como universo empírico. Uma das premissas principais que sustentou o trabalho é que o futebol moderno é uma instituição disciplinadora e civilizadora.

No futebol moderno, basicamente tudo é ensinado, exceção do talento, que é algo natural, porém aperfeiçoado por meio de treinamentos.

Com a diminuição dos campos de várzea, devido ao crescimento urbano acentuado, a escolinha de futebol ganha relevo especial. O aprendizado do futebol desloca-se para as escolinhas dos clubes. É nas divisões de base dos clubes profissionais que ocorre o processo de ensino de futebol e, conseqüentemente a profissionalização do jogador. Nas escolinhas de futebol, tudo se ensina: as técnicas, as regras, as condutas, a preparação e o uso do material esportivo.

Podemos sintetizar o que foi exposto neste trabalho da seguinte forma: (1) O futebol surge no Brasil como um produto da modernidade. Seu desenvolvimento segue dinâmica similar aos demais setores da sociedade, em que a modernização implica a intervenção da ciência; (2) O controle social, os treinamentos e a repressão, os mecanismos principais no disciplinamento na formação do atleta; (3) O dom, o sonho de enriquecer, o incentivo da família e a seleção brasileira são as motivações pelo futebol.

A produção social do jogador de futebol, especialmente com o advento dos CTs, decorrente da recente modernização, consiste em um processo de disciplinamento, adaptação, socialização, adestramento, desenvolvimento e aperfeiçoamento das potencialidades físicas e técnicas do 
atleta, além da administração do seu potencial genético. Trata-se, pois, de um processo disciplinador, pedagógico e civilizatório caracterizado pela regulamentação, controle, institucionalização e racionalização. O jogador de futebol é uma força de trabalho produto do disciplinamento, treinamentos físicos, técnicos e táticos e do desenvolvimento de suas capacidades genéticas. Recebe uma formação profissional.

Em síntese, a formação do jogador de futebol consiste num processo de aprendizagem e disciplinamento teórico-prático, em treinamentos físicos, técnicos e táticos. O disciplinamento do jogador ocorre através de dispositivos especiais (tais dispositivos podem ser entendidos no sentido abordado por Foucault $(1987,2001))$. A incorporação de normas, regras e técnicas faz parte da formação técnica e social (uma dimensão do processo civilizador) do jogador de futebol (no sentido trabalhado por Elias, 1992).

Portanto, o jogador de futebol passa por uma formação profissional. É necessário que o jogador freqüente escolas especiais e que receba treinamentos de técnicas futebolísticas. $\mathrm{O}$ jogador de futebol brasileiro não nasce feito, é produzido socialmente, ou seja, é formado em instituições especializadas.

\section{Referências}

ARAÚJO, R. B. de. Os gênios da pelota: um estudo do futebol como profissão. 1980. Dissertação (Mestrado em Antropologia Social) - PPGAS/Museu Nacional/ UFRJ, Rio de Janeiro.

ANTUNES, F. O futebol nas Fábricas. Revista USP, no 22 (Dossiê Futebol), jun./jul./ ago. São Paulo: USP, 1994.

BOURDIEU, P. A Economia das Trocas Simbólicas. 5a ed. São Paulo: Editora Perspectivas, 1999.

BOURDIEU, P. Programa para uma Sociologia do Esporte. In: BOURDEIU, P. Coisas Ditas. São Paulo: Brasiliense, 1990. 
Sociologias, Porto Alegre, ano 6, no 11, jan/jun 2004, p. 260-299

BRACHT, V. Sociologia Crítica do esporte: uma introdução. Vitória: UFES, 1997.

CALDAS, W. O Pontapé Inicial: Memória do Futebol Brasileiro. São Paulo: IBRASA, 1990.

CARRAVETTA, É. O Jogador de Futebol: Técnicas, Treinamento e Rendimento. Porto Alegre: Mercado Aberto, 2001.

CASTRO, R. Estrela solitária: um brasileiro chamado Garrincha. São Paulo: Cia. das Letras, 1995.

$\mathrm{DAMO}, \mathrm{A}$. S. Futebol e identidade social: uma leitura antropológica das rivalidades entre torcedores e clubes. Porto Alegre: Editora da UFRGS, 2002, (Coleção academia).

ELIAS, N. A busca de excitação. Lisboa: Difel, 1992.

FLORENZANO, J. P. Afonsinho e Edmundo: a rebeldia no futebol brasileiro. São Paulo: Editora Musa, 1998.

FREYRE, G. Futebol brasileiro e dança. In: FREYRE, G. Seleta para jovens. Rio de Janeiro: Editora José Olympio,1971.

FREYRE, G. Introdução. In: RODRIGUES FILHO, M. O Negro no Futebol Brasileiro. Rio de Janeiro: Editora Civilização Brasileira, 1964.

FOUCAULT, M. Microfísica do poder. 16 $\mathbf{a}$ ed. Rio de Janeiro: Graal, 2001.

FOUCAULT, M. Vigiar e Punir: nascimento da prisão. 7a ed. Petrópolis: Vozes, 1987.

GIDDENS, A. As conseqüências da modernidade. São Paulo: UNESP, 1991.

GIL, G. O drama do "futebol-arte": o debate sobre a seleção nos anos 70. Revista Brasileira de Ciências Sociais. São Paulo, no 25, ano 9, junho de 1994.

GUEDES, S. L. O Brasil no campo de futebol: estudos antropológicos sobre os significados do futebol brasileiro. Rio de Janeiro: EDUFF, 1998.

HARVEY, D. A condição pós-moderna. São Paulo: Editora Loyola, 1992. 
HELAL, R. Passes e impasses: futebol e cultura de massa no Brasil. Rio de Janeiro: Vozes, 1997.

HELAL, R. O que é sociologia do esporte. São Paulo: Brasiliense, 1990 (Coleção Primeiros Passos).

LACLAU, E. New reflections on the resolution of our time. Londres: Verso, 1990.

LEVER, J. A loucura do futebol. Rio de Janeiro: Record, 1983.

LEVINE, R. Esporte e sociedade: o caso do futebol brasileiro. In: MEIHY, J. J. S. B e WITTER, J. S. (Orgs.). Futebol e cultura: coletânea de estudos. São Paulo: Convênio Imesp/Daesp, 1982.

LOPES, J. S. L. Futebol Mestiço. Ciência Hoje, SBPC, v.24, no 139, junho 1998.

LOPES, J. S. L. A vitória do futebol que incorporou a pelada. In: Revista USP, n. 22 (Dossiê Futebol), jun./jul./ago. São Paulo: USP, 1994a.

LOPES, J. S. L. e FAGUER, J.-P. I'Invention du Style Brésilien: sport, journalism et politique au Brésil. Actes de la Recherche Sciences Sociales, École de Hautes Etudes en Sciences Sociales, Paris, 103, jun/1994b, pp.27-35.

LOPES, J. S. L. A morte da alegria do povo. Revista Brasileira de Ciências Sociais. São Paulo, nº 20, 1992.

MACHADO, R. Por uma genealogia do poder. In: FOUCAULT, Michel. Microfísica

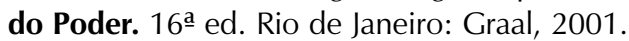

MOURA, G. de A. O Rio corre para o Maracanã. Rio de Janeiro: Editora da FGV, 1998.

OSTERMANN, R C. Meu coração é vermelho. Porto Alegre: Mercado Aberto, 1999.

PEREIRA, L. Footballmania: uma história social do futebol no Rio de Janeiro (19021938). Rio de Janeiro: Nova Fronteira, 2000.

PIMENTA, C. A M. Novos Processos de Formação de Jogadores de Futebol e fenômeno das "escolinhas": uma análise crítica do possível. In: Peligro de Gol: 
Sociologias, Porto Alegre, ano 6, no 11, jan/jun 2004, p. 260-299

estúdios sobre deporte y sociedad en América Latina. ALABARCES, Pablo (compilador). Colección Grupos de Trabajo de CLACSO, Grupo de Trabajo: Deporte y Sociedad, Buenos Aires: CLACSO, abril del 2000.

Revista Placar, no 1.191, Editora Abril, 07/08/2001.

RODRIGUES FILHO, M. O negro no futebol brasileiro. São Paulo: Civilização Brasileira, 1964.

RODRIGUES, F. X. F. A Formação do Jogador de Futebol no Sport Club Internacional (1997-2002). Porto Alegre: PPGS/UFRGS, 2003. (Dissertação de Mestrado em Sociologia).

ROSENFELD, A. Negro, macumba e futebol. São Paulo: Edusp/Perspectiva, 1993.

TOLEDO, L. H. Lógicas no futebol. São Paulo: Hucitec/Fapesp, 2002.

WEBER, M. Ciência e política: duas vocações. São Paulo: Editora Cultrix, 1968.

\section{Outras fontes}

Gazeta Esportiva. 16/11/1986 e 23/01/1997.

O Globo. 20/02/1996. Esportes.

Zero Hora. 17/05/1997. Cadernos de Esportes.

Folha de São Paulo. 09/01/1996. Esportes.

Diário Popular. 09/01/1996.

Recebido: 18/08/2003

Revisado: 30/09/2003

Aceite final: 10/10/2003 
Sociologias, Porto Alegre, ano 6, o 11, jan/jun 2004, p. 260-299

\section{Resumo}

O trabalho investiga a relação entre modernidade, disciplina e formação do jogador de futebol profissional. Discute o futebol moderno como instituição disciplinadora, dotada de regras, normas e princípios científicos (positividades), tendo como objetivo produzir, manipular, individualizar, adestrar e aperfeiçoar o corpo do indivíduo, tornar o jogador dócil e utilitário. A modernidade, caracterizada pela secularização, subjetivação, triunfo da racionalidade instrumental, domínio da natureza e o surgimento do indivíduo moderno, transforma o ser humano em objeto de conhecimento. O campo empírico da investigação é formado pelas categorias de base do Internacional (RS). A pesquisa constata que a produção social do jogador de futebol consiste num processo de disciplinamento, adaptação, socialização, adestramento, desenvolvimento e aperfeiçoamento das potencialidades físicas e técnicas do atleta, além da administração do seu potencial genético. Trata-se de um processo disciplinador, pedagógico e civilizatório, caracterizado pela regulamentação, controle, institucionalização e racionalização. O jogador de futebol é uma força de trabalho, produto do disciplinamento, treinamentos físicos, técnicos e táticos e do desenvolvimento de suas capacidades genéticas.

Palavras-chave: modernidade, futebol, corpo, disciplina. 